\title{
DIAGNÓSTICO DA ESQUISTOSSOMOSE MANSÔNICA MEDIANTE TÉCNICA DE IMUNOFLUORESCÊNCIA COM ESPOROCISTOS EM TECIDOS DE PLANORBIDEOS
}

\begin{abstract}
GUARALDO, A. M. A. et al. Diagnóstico da esquistossomose mansônica mediante técnica de imunofluorescência com esporocistos em tecidos de planorbídeos. Rev. Saúde públ., S. Paulo, 15:623-8, 1981.

RESUMO: Propõe-se uma técnica de imunofluorescência para diagnóstico da esquistossomose mansônica, adotando-se tecidos de Biomphalaria glabrata contendo esporocistos secundários de Schistosoma mansoni. A reação de imunofluorescência indireta é execulada sobre cortes histológicos preparados por inclusão em parafina.
\end{abstract}

UNITERMOS: Esquistossomose mansônica. Imunofluorescência. Biomphalaria glabrata. Schistosoma mansoni.

\section{INTRODUÇÃO}

A primeira tentativa para diagnóstico da esquistossomose mediante emprego da técnica para deteç̧ão de anticorpos por imunofuorescência deve-se a Sadun e col.13 (1960), que obtiveram resultados excelentes com cercárias e miracídios. A principal desvantagem na aplicação desta metodologia consiste na ocorrència de reações cruzadas com anticorpos contra Trichinella spiralis, Fasciola gigantica e alguns trematódeos de aves, roedores e bovinos (Sadun e Biocca ${ }^{12}$, 1962; Pellegrino e Biocca 15, 1963; Amin e col. $\left.{ }^{1}, 1969\right)$. Este inconveniente fica atenuado porque a distribuição geográfica da triquinelose e da esquistossomose não é coincidente.

Diante da possibilidade do aproveitamento da imunofluorescência indireta como rotina nos laboratórios, tornou-se imprescindivel o aprimoramento deste método, visando obtenção de material antigênico mais estável e passivel de maior rendimento e disponibilidade. Durante algum tempo as cercárias foram consideradas como forma antigênica preferida para diagnóstico da esquistossomose pela imunofluorescência (Anderson e col."2, 1961). Entretanto, a execução desta técnica requer manutenção constante do ciclo do Schistosoma mansoni em laboratório, além de dispender muito tempo e material.

Para inquéritos epidemiológicos, os trabalhos de Camargo e col. ${ }^{5}$ (1965) e Le Viguelloux e col. ${ }^{9}$ (1969) preconizaram a reação com partículas de esquistossomos adultos liofilizados e aderidos em lâminas. Entretanto, os mesmos autores encontraram

* Do Instituto de Biologia da UNICAMP - Cai ra Postal 6119 -- 13100 - Campinas, SP - Erasil.

* Da Universidade Federal do Maranhão - Programa de Pesquisa e Pós-graduação ta Imunoløgia. Campus Universitário do Bacanga, sala 3A - 65000 - São Luís, MA - Brasil. 
GUARALDO, A.M.A. et al. Diagnóstico da esquistossomose mansónica mediante técnica de imunofluorescência com esporocistos em tecidos de planorbideos. Rev. Saúde públ., S. Paulo, $15: 623-8$, 1981 .

dificuldade na interpretação dos resultados, devido interferência de reações inespecíficas. Este problema foi minimizado por Coudert e col.6 (1967) mediante o preparo de cortes de congelação utilizando vermes em fígados de animais parasitados. A autofluorescência do helminto foi atenuada com coloração de contraste pelo azul de Evans (Fry e Wilkinson 7, 1963).

Recentemente, inúmeros pesquisadores têm adotado cortes de vermes adultos não fixados e incluídos em meio próprio (TissueTek O.C.T.) segundo técnica recomendada por Wilson e col.14 (1974). Este método tem sido apontado como de maior sensibilidade e especificidade. Um inconveniente é, entretanto, a exigência de criostato, aparelho dispendioso que vários laboratórios não têm condição de adquirir. Na tentativa de suprimir a necessidade do criostato, Rombert 11 (1968) desenvolveu um método de imunofluorescência adotando reação em lâmina com partículas de hepatopâncreas de molusco infectado com Schistosoma mansoni. A positividade das reações com este material fixado com acetona foi de $96 \%$, revelando algumas reaçōes inespecificas com soros pouco diluídos. Posteriormente, Kien Truong e col.8 (1970) também adotaram para imunofluorescência indireta cortes congelados de hepatopâncreas de Biomphalaria glabrata parasitada, na investigação da seqüência do aparecimento e evolução de anticorpos em camudongos experimentalmente infectados por S. mansoni.

Considerando os fatos mencionados, parece oportuno sugerir a utilização de método mais simples para obtenção de material antigênico que atenda as principais exigências de estabilidade, especificidade, sensibilidade, bom rendimento e custo accessível. Ocorreu-nos a opção de utilizar tecidos de moluscos parasitados pelo Schistosoma mansoni. $\mathrm{O}$ material antigênico em questão é fornecido por esporocistos secundários maduros encontrados principalmente em ovotestis e hepatopâncreas do hospedeiro intermediário. As reações de imunofluorescência podem ser executadas sobre cortes histológicos destes órgãos devidamente incluídos em parafina.

\section{MATERIAL E METODOS}

\section{Antissoros}

Foram utilizados dois sistemas para aplicação da técnica de imunofluorescência indireta. No primeiro sistema os soros imunes foram produzidos em coelhos contra extrato bruto de esquistossomos adultos, obtidos de camundongos infectados experimentalmente com cercárias eliminadas por Biomphalaria glabrata. O esquema adotado para imunização de coelhos foi estabelecido por Bastos e col. ${ }^{3}$ (1978). Os antissoros assim obtidos foram titulados previamente por hemaglutinação indireta com reagente "Behring" para esquistossomose, apresentando alto teor de anticorpos aglutinantes (título de 16.384).

No segundo sistema foram processadas reações com imunessoros de camundongos Swiss albinos submetidos a infeç̧ão com 100 cercárias de Schistosoma mansoni eliminadas por Biomphalaria glabrata. Tanto o grupo de animais controles como dos infectados representam o soro de 10 camundongos sacrificados semanalmente, da primeira até oitava semana da infecção pelas cercárias. O grupo dos infectados recebeu a sigla In e dos controles, $C n$ (seja $n$ equivalente ao número de semanas que transcorreram desde a data da infecção pelo $S$. mansoni).

\section{Conjugados Fluorescentes}

Para o sistema proposto com soro de coelhos imunes utilizou-se como conjugado fluorescente a fração globulínica de soro de carneiro anti IgG de coelho, preparado em nosso laboratório. A purificação do antissoro de carneiro foi obtida mediante cromatografia em coluna de DE-52 celulose mediante eluição com gradiente de $\mathrm{pH}$ e força iônica com tampão fosfato. As frações eluídas com

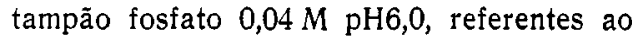


GUARALDO, A.M.A. et al. Diagnóstico da esquistossomose mansônica mediante técnica de imunofluorescência com esporocistos em tecidos de planorbídeos. Rev. Saude públ., S. Paulo, $\mathbf{1 5}: 623-8,1981$.

terceiro pico, corresponderam, eletroforeticamente à $\operatorname{IgS}$ do soro de carneiro. Estas frações foram devidamente liofilizadas para serem conjugadas com isotiocianato de fluoresceina. O excesso de fluorocromo livre foi retirado mediante cromatografia em coluna de Sephadex G-25 previamente equilibrado com tampão fosfato de sódio $0,01 \mathrm{M}$ pH 7,2. Das frações eluídas foi determinada a relação Fluoresceina/Proteína $(\mathrm{F} / \mathrm{P})$ avaliada em 1,8. A melhor diluição do conjugado para as reações foi de $1 / 30$.

No caso da revelação das reações com soros de camundongos foi adotado o conjugado "Hyland Lab." (soro de cabra anti-imunoglobulina $7 \mathrm{~S}$ de camundongo) na diluição $1 / 50$.

\section{Antigenos}

Foram adotadas cinco categorias de preparaçōes antigênicas:

1. cercárias livres, recém eliminadas, fixadas, em formol $0,5 \%$.

2. miracídios livres, recém eclodidos, fixados em formol $0,5 \%$.

3. esquistossomos adultos, de ambos os sexos, liofilizados.

4. esquistossomos adultos, de ambos os sexos, incluídos em parafina.

5. esporocistos primários e secundários, em cortes histológicos de Biomphalaria glabrata devidamente incluida em parafina.

Apenas as preparaçōes 1 e 2 tiveram as reaçōes executadas em tudo de ensaio.

As preparaçoes destinadas a cortes histologicos em parafina foram fixadas em líquido de Rossman $(90 \mathrm{ml}$ de álcool etílico $100 \%$ saturado com ácido pícrico e $10 \mathrm{ml}$ de formoldeido $37 \%$ ) durante $2 \mathrm{~h}$. Após processamento rotineiro para inclusão em parafina foram levados ao micrótomo ajustado para 7 micra. Os cortes histológicos assim obtidos sofreram desparafinização e hidratação a fim de receberem soro imune descomplementado, na diluição $1 / 8$.

\section{Reaçāo de Imunofluorescência Indireta}

Estas reaçōes foram idênticas, tanto para - material processado em tubo como para aqueles preparados em lâminas de microscopia. Antes de receberem o soro, as preparações sofreram três lavagens sucessivas com solução salina tamponada (PBS 0,01 M $\mathrm{pH}$ 7,2). As làminas foram secas parcialmente e os imunessoros diluídos a $1 / 8$ adicionados sobre as preparações para reagirem à temperatura ambiente em câmara úmida durante $45 \mathrm{~min}$. Decorrido o tempo de reação, os materiais foram lavados três vezes com $\mathrm{PBS}$ com duração mínima de 2 min. em cada lavagem. O excesso de PBS foi retirado e adicionou-se o respectivo conjugado contendo azul de Evans na proporção adequada (diluição $1: 10.000$ para conjugado de soro de camundongo e diluição 1:5.000 para conjugado de soro de coelhos). Após adição do conjugado, as preparações foram colocadas no escuro, no interior de uma estufa a $37^{\circ} \mathrm{C}$, durante $45 \mathrm{~min}$. Após a remoção do conjugado, todas as lâminas foram montadas em glicerina alcalina tamponada, $\mathrm{pH} 9,0$.

Os controles utilizados foram os seguintes:

1 - apenas tampão; 2 - apenas conjugado; 3 - soro normal de coelho (ou camundongo) + conjugado especifico; 4 - inibição da fluorescência : soro imune de coelho (ou camundongo) + anti-imunoglobulina não fluorescente + conjugado específico; 5 - tratamento de tecido de molusco não parasitado.

O resultado da fluorescência foi obtido mediante exame das lâminas ao microscópio Zeiss com lâmpada de mercúrio UV (HBO 200) e filtros barreira $0 / 47 / 44$ com excitador I e condensador de campo escuro.

A avaliação da especificidade dos antissoros disponiveis foi possivel mediante absorção dos imunessoros com vermes liofilizados. Para isto incubou-se a mistura antigeno-anticorpo durante $18 \mathrm{~h}$ em refrigerador a $4^{\circ} \mathrm{C}$. O soro foi separado por centrifugação. 
GUARALDO, A.M.A. et al. Diagnóstico da esquistossomose mansônica mediante técnica de imunofluorescência com esporocistos em tecidos de planorbideos. Rev. Saúde públ., S. Paulo, $15: 623-8,1981$.

\section{RESULTADOS E DISCUSSAO}

As reações de imunofluorescência e de hemaglutinação acusaram resultado negativo quando testadas com imunessoros absorvidos com esquistossomos liofilizados. Considerando que na imunofluorescência foram adotadas preparações de miracídios, esporocistos primários, esporocistos secundários, cercárias e esquistossomos de ambos os sexos, o desaparecimento da fluorescência atesta a existência de determinantes antigênicos comuns do verme adulto com todas as fases larvares do Schistosoma mansoni. Esta conclusão é fundamentada nos resultados apresentados pelos soros de coelhos imunizados apenas com vermes adultos de ambos os sexos do $S$. mansoni.

Quando se analisam os resultados encontrados com utilização de soros de camundongos em diferentes estágios da doença frente aos diversos preparados antigênicos, observa-se que os primeiros anticorpos formados são específicos para o tubo digestivo do parasita, aparecendo a partir da terceira semana de infecção, conforme ilustrado na Tabela (Bastos 4 , 1979). Os imunessoros das semanas subseqüentes originaram fluorescência também no tegumento do verme. Cercárias e miracídios revelaram-se fluorescentes com tratamento de soros colhidos a partir da quarta semana de infecção. As cercárias presentes nos esporocistos secundários apresentaram fluorescência quando tratadas com soros de camundongos com seis semanas de infecção e a reação torna bastante intensa para a parede do esporocisto a partir da sétima semana.

As cercárias em desenvolvimento no interior dos esporocistos encontram-se em diferentes estágios de diferenciação e pudemos notar fraca fluorescência localizada no tegumento daquelas cercárias que ainda não diferenciaram o acetábulo. A medida que as cercárias vão se diferenciando com formação da cauda bifurcada, a fluorescência tende a aumentar de intensidade, surgindo forte reação ao nivel da ventosa ventral e, concomitantemente, a parede do esporocisto torna-se intensamente corada (Fig.).

Todas as reações obtidas com soros controles acusaram resultados negativo para fluorescência.

TIA B ELA

Reações de imunofluorescência obtidas com soros imunes de camundongos infectados com Schistosoma mansoni para estágios evolutivos do verme.

\begin{tabular}{|c|c|c|c|c|c|}
\hline Soros & $\begin{array}{l}\text { Reações em } \\
\text { miracídios }\end{array}$ & $\begin{array}{l}\text { Tubos } \\
\text { cercárias }\end{array}$ & $\begin{array}{l}\text { Reações } \\
\text { esporocistos } \\
\text { primários }\end{array}$ & $\begin{array}{l}\text { em cortes } \\
\text { esporocistos } \\
\text { secundários }\end{array}$ & $\begin{array}{l}\text { Histológicos } \\
\text { esquistossomos }\end{array}$ \\
\hline$I_{1}$ & - & - & - & - & - \\
\hline $\mathrm{I}_{2}$ & - & 一 & - & - & - \\
\hline$I_{3}$ & - & - & - & - & + \\
\hline$I_{4}$ & + & + & - & - & + \\
\hline $\mathrm{I}_{5}$ & + & - & - & - & + \\
\hline$I_{6}$ & ++ & ++ & - & + & +1 \\
\hline$I_{7}$ & $+t+$ & $+t+$ & - & ++ & +++ \\
\hline$I_{8}$ & $++t$ & $++t$ & + & $+t+$ & $+t+$ \\
\hline $\mathrm{C}_{8}$ & - & - & - & - & $\cdot-$ \\
\hline
\end{tabular}

In e $\mathrm{Cn}=$ soro imune $(\mathrm{I})$ e controle (C) obtidos semanalmente $(\mathrm{n}$ ) após exposição a cercárias. Reacões negativas (-) e positivas $(+)$ em diferentes intensidades. 
GUARALDO, A.M.A. et al. Diagnóstico da esquistossomose mansônica mediante técnica de imunofluorescência com esporocistos em tecidos de planorbídeos. Rev. Saúde públ., S. Paulo, $15: 623-8,1981$.

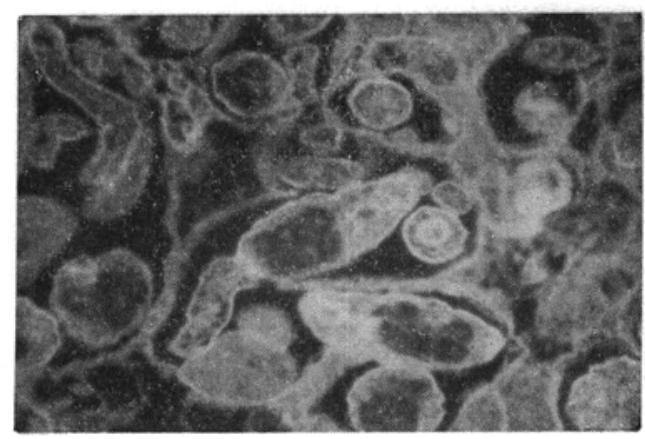

Fig. - Esporocistos secundários de Schistosoma mansoni em hepatopâncreas de Biomphalaria glabrata. Cercárias em desenvolvimento mostram tegumento fli:orescente e maior intensidade de fluorescência ao nível de ventosas oral e acetabular. Parede dos esporocistos com reação positiva.

Nas reaçōes realizadas com esporocistos primários de $S$. mansoni observou-se fraca fluorescência na parede do esporocisto a partir da primeira semana de desenvolvimento no invertebrado, adotando-se imunessoro coletado após oito semanas da infecção em camundongos. $O$ mesmo resultado foi observado quanto ao tratamento destes esporocistos com soros obtidos pela imunização de coelhos com vermes adultos. Os melhores resultados foram produzidos com tratamento de soros de coelhos na diluição $1: 8$, em todos os tipos de preparaçōes.

A utilização de esporocistos primários para fins de diagnóstico é desaconselhável devido a dificuldade de reconhecimento em cortes histológicos, além de seu tamanho diminuto.

A reprodução dos resultados com preparados histológicos de hepatopâncreas e ovotestis contendo esporocistos secundários de $S$. mansoni indica que esta técnica proporcionou boa preservação de antígeno associada a possibilidade de grande número de reações com um único planorbídeo, sem a necessidade de conservação à baixa temperatura. $O$ volume de soro necessário para execução da reação é de 50 a 100 microlitros, o suficiente para garantir a exposição de toda área do corte histológico. $\mathrm{O}$ rendimento desta técnica adotando-se tecidos de moluscos parasitados mostrou-se muito superior à utilização de cortes de esquistossomos incluidos em parafina, que se mostram às vezes com coloração inespecífica. As preparações constituídas por esquistossomos liofilizados deram melhor resultado que as obtidas em cortes histológicos pela ausência de coloração inespecífica.

Recomendamos avaliar a sensibilidade e especificidade desta nova técnica comparando-a com os resultados de soros já padronizados por outros métodos. Para trabalhos de campo é interessante avaliar o comportamento de amostras de sangue de doentes, recolhidas em papel de filtro, a fim de comparar o título dos soros frente a este tipo de preparação antigênica.

GUARALDO, A. M. A. et al. [Diagnosis of mansoni schistosomiasis by means of immunofluorescent technique using sporocysts in planorbid tissues]. Rev. Saúde publ., S. Paulo, 15:623-8, 1981.

ABSTRACT: An immunofluorescent technique is proposed for diagnosis of mansoni schistosomiasis using Blomphalaria glabrata tissue with secondary sporocysts. The indirect immunofluorescent reaction is carried out on histological sections prepared by embedding in paraffin.

UNITERMS: Schistosomiasis. Fluorescent antybody technic. Biomphalaria glabrata. Schistosoma mansoni. 
GITARALDO, A.M.A. et al. Diagnóstico da esq: istossomose mansônica mediante técnica de imunofluorescência com esporocistos em tecido's de planorbídeos. Rev. Saúde públ., S. Paulo, 15:623-8, 1981.

\section{REFERENCIAS BIBLIOGRAFICAS}

1. AMIN, M.A. et al. Cross serological reaction between human and animal schistosomes by the fluorescent antibody technique in some laboratory animals. Ann. trop. Med. Parasit., 63:373-5, 1969.

2. ANDERSON, R.I. et al. Preserved cercariae in the fluorescent antibody (FA) test for schistosomiasis. Exp. Parasit., 22 226-30, 1961.

3. BAstos, 0 . de $C$. et al. Alguns dados sobre o comportamento parasitologico das linhagens humana e silvestre do Schistosoma mansoni no vale do Rio Paraíba do Sul, SP (Brasil). Rev. Saúde públ., S. Paulo, 12:184-99, 1978.

4. BASTOS, 0 . de C. Utilização de soros pluri-especificos no estudo da evolução das imunoglobulinas envolvidas na resposta imune de camundongos ao Schistosoma mansoni. Campinas, 1979. [Tese de Doutoramento - Instituto de Biologia da Universidade Estadual de Campinas].

5. CAMARGo, M.F. et al. A slide fluorescent antibody technique with adult worm antigen for the serological diagnosis of schistosomiasis mansoni. Rev. Inst. Med. trop. S. Paulo, 7:327-31, 1965.

6. COUdERT, J, et al. Premiers résultats à propos du diagnostic sérologique de la bilharziose par imt:nofluorescence sur coupes à la congelation de Schistosoma mansoni. Ann. Parasit. hum. comp., 42: 483-92, 1967.

7 FRY, C.S. \& WILKINSON, A.E. $A$ note on the use of Evans blue as a background stain in the FTA-test. G`neva, World Health Organization, 1963. (WHO/VDT/Res, 35).
8. KIEN TRUONG, $T$. et al. Comparative evolution of the fluorescent antibodies directed against the larval stages and the adults of Schistosoma mansoni. I. Experimental schistosomiasis in untreated mice. Ann. trop. Med. Parasit., 64:87-92, 1970.

9. LE VIGELLOUX, J. et al. Réactions d'imunofluorescence sur broyat de Schistosoma mansoni. Résultats complementaires, $M e ́ d$. trop., 29:680-4, 1969 .

10. PELLEGRINO, J. \& BIOCCA, E. Diagnóstico sorológico de esquistossomose mansônica. II. Reação de imunofluorescência com cercárias de Schistosoma bovis e cercária caratinguensis. Rev. Inst. Med. trop. S. Paulo, 5:257-60, 1963.

11. ROMBERT, P.C. Uma nova técnica de imunofluorescência para o serodiagnóstico da bilharziose. An. Esc. nac. Saúde públ. Med. trop., Lisboa, 2:175-83, 1968.

12. SADUN, E.H. \& BIOCCA, E. Intradermal and fluorescent antibody tests on humans exposed to Schistosoma bovis cercariae from Sardinia. Bull. Wld Hith org., $27: 810-4,1962$.

13. SADUN, E.H. et al. Fluorescent antibody technique for serodiagnosis of schistosomiasis in human. Proc. Soc. exp. Biol., 105 : 287-91, 1960.

14. WILSON, M. et al. Modified antigens in the indirect immunofluorescence test for schistosomiasis. Amer. J. trop. Med. Hyg., 23:1072-6, 1974.

Recebido para publicação em 21/05/1981

Aprovado para publicação em 07/10/1981 